\title{
Understanding the Great Ordovician Biodiversification Event (GOBE): Influences of paleogeography, paleoclimate, or paleoecology?
}

\begin{abstract}
Thomas Servais, Equipe "Paléontologie et Paléogéographie du Paléozoïque," UMR 8157 du CNRS "Géosystèmes," Université de Lille 1, F-59655 Villeneuve d'Ascq, France; David A.T.

Harper, Statens Naturhistoriske Museum (Geologisk Museum), Øster Voldgade 5-7, DK-1350 København K, Denmark; Jun Li, Institute of Geology and Palaeontology, Chinese Academy of Sciences (NIGPAS), Chi-Ming-Ssu, Nanjing 210008, China;

Axel Munnecke, GeoZentrum Nordbayern, Loewenichstraße 28, 91054 Erlangen, Germany; Alan W. Owen, Dept. of Geographical \& Earth Sciences, University of Glasgow, Gregory Building, Lilybank Gardens, Glasgow G12 8QQ, Scotland, UK; and Peter M. Sheehan, Geology Dept., Milwaukee Public Museum, 800 West Wells Street, Milwaukee, Wisconsin 53233, USA
\end{abstract}

\begin{abstract}
"The Great Ordovician Biodiversification Event" (GOBE) was arguably the most important and sustained increase of marine biodiversity in Earth's history. During a short time span of $25 \mathrm{Ma}$, an "explosion" of diversity at the order, family, genus, and species level occurred. The combined effects of several geological and biological processes helped generate the GOBE. The peak of the GOBE correlates with unique paleogeography, featuring the greatest continental dispersal of the Paleozoic. Rapid sea-floor spreading during this time coincided with warm climates, high sea levels, and the largest tropical shelf area of the Phanerozoic. In addition, important ecological evolutionary changes took place, with the "explosion" of both zooplankton and suspension feeding organisms, possibly based on increased phytoplankton availability and high nutrient input to the oceans driven by intense volcanic activity. Extraterrestrial causes, in the form of asteroid impacts, have also been invoked to explain this remarkable event.
\end{abstract}

\section{INTRODUCTION}

Although the five major mass extinctions (in particular, the Permian-Triassic and the Cretaceous-Tertiary events) have been extensively documented, until recently, the major biodiversifications and radiations of life on Earth have attracted much less attention. The so-called "Cambrian explosion" is in many ways much better known than the Ordovician and
Mesozoic-Cenozoic radiations of marine invertebrates. Although the Cambrian explosion resulted in a range of new and spectacular animal body plans, mostly known from famous FossilLagerstätten, such as the Burgess Shale (Canada), Chengjiang (China), and Sirius Passet (Greenland), the Ordovician radiation is dramatic in different ways (Droser and Finnegan, 2003) and is evident in the "normal" shelly fossil record.

The term "The Great Ordovician Biodiversification Event" (GOBE) has been introduced to designate what is arguably the most important increase of biodiversity of marine life during Earth's history (Webby et al., 2004). While the "Cambrian explosion" involved the origins of skeletalization and a range of new body plans, the Ordovician biodiversification generated few new higher taxa but witnessed a staggering increase in disparity and biodiversity (e.g., Harper, 2006).

Barnes et al. (1995) reviewed the global bio-events during the Ordovician, and two international research projects have since targeted the Ordovician biodiversification. International Geoscience Programme (IGCP) Project 410, "The Great Ordovician Biodiversification Event" (1997-2002), resulted in a compilation of biodiversity curves for all fossil groups of the Ordovician biota (Webby et al., 2004). In this compilation, the dramatic increase of diversity of all groups at the specific and/or the generic level became obvious and confirmed the patterns based on previous diversity counts (e.g., Sepkoski, 1981). IGCP 503 started in 2004 under the banner of "Ordovician Palaeogeography and Palaeoclimate" and has focused on the causes and the geological context of the Ordovician biodiversification, including radical changes in the marine trophic chains. Possible triggers of the GOBE may include the near-unique paleogeography, the distinctive paleoclimate, the highest sea levels of the Paleozoic (if not the entire Phanerozoic), enhanced nutrient supply as a result of pronounced volcanic activity, and major ecological changes. In addition to these Earth-bound physical and biological drivers of biodiversity change, Schmitz et al. (2008) linked the onset of the major phase of the Ordovician biodiversification with the largest documented asteroid breakup event during the past few billion years. It seems likely that the GOBE was linked to a variety of coincident and interconnected factors. Here we review recent studies, ask "What generated the GOBE?" and indicate the perspectives for future research in this exciting and rapidly advancing field.

GSA Today, v. 19, no. 4/5, doi: 10.1130/GSATG37A.1

E-mails: thomas.servais@univ-lille1.fr, dharper@snm.ku.dk, junli@nigpas.ac.cn, axel.munnecke@pal.uni-erlangen.de, alan.owen@ges.gla.ac.uk, sheehan@mpm.edu. 


\section{THE GREAT ORDOVICIAN BIODIVERSIFICATION EVENT (GOBE)}

The "Cambrian explosion" and the GOBE were the two most significant evolutionary events in the history of Paleozoic marine life. Most animal phyla were already present by the midCambrian, but a dramatic diversity increase at the order, family, and genus levels took place in the Ordovician, during which marine paleobiodiversity tripled (Harper, 2006). Based on multivariate statistical analyses, Sepkoski (e.g., 1981, 1991) defined three Evolutionary Faunas (EF-the Cambrian, Paleozoic, and Modern Evolutionary Faunas) and indicated that during the Ordovician, the Paleozoic EF, dominated by groups of suspension-feeding organisms, became the most significant component of the marine shelf biotas (Fig. 1). In addition to the EFs, other authors have defined Ecological-Evolutionary Units (EEUs) - long intervals of Phanerozoic time during which marine communities maintained stable ecological structures. The 12 EEUs, defined by Boucot (1983), were revised by Sheehan (1996, 2001a), who reduced their number to nine. Four EEUs are defined primarily on the Paleozoic EF, with two (P1 and P2) recognized in the Ordovician (Fig. 1A), and distinguished on the basis of taxonomic diversity, morphological disparity, and ecological change (Sheehan, 1996; Droser et al., 1997; Droser and Sheehan, 1997).

Several authors have considered the GOBE to be rooted in the 545-530 Ma Cambrian explosion (e.g., Droser and Finnegan, 2003). Our knowledge of Cambrian faunas is enhanced by exceptionally preserved assemblages (e.g., the Burgess Shale) that allow a glimpse of the range of new body plans generated by the Cambrian explosion. Early molecular-clock data suggested that animal lineages split some $800 \mathrm{Ma}$ or more ago before their appearance in the fossil record (Wray et al., 1996), but this has been recalibrated to ca. $670 \mathrm{Ma}$ (e.g., Peterson et al., 2005). After the Cambrian explosion, 40-80 Ma passed before the diversity of the new phyla "exploded" during the Early and Middle Ordovician (485-460 Ma). This "explosion" in terms of diversity at the order, family, genus, and species level occurred during a short time span of only $25 \mathrm{Ma}$, which is why the GOBE is considered the most rapid diversity increase in marine life during Earth's history. By the end of the Middle Ordovician, the so-called Paleozoic Plateau, evident in the diversity curves generated by Sepkoski, was reached, and it persisted until the abrupt Permian-Triassic extinction 200 Ma later (Fig. 1A). Even in the more recent biodiversity curves that take account of potential biases in the earlier analyses, the major biodiversification that occurred during the Ordovician is clear (e.g., Alroy et al., 2008).

\section{ORDOVICIAN PALEOGEOGRAPHY}

The Cambrian-Ordovician and the Mesozoic-Cenozoic increases of marine diversity have long been related to largescale paleogeographical changes (e.g., Crame and Owen, 2002; but see also Alroy et al., 2008, who considered the younger of the two diversifications to have culminated in the mid-Cretaceous). Valentine and Moores (1972) proposed a link between the break-up of the Neoproterozoic supercontinent (subsequently termed Rodinia or Pannotia) and the Cambrian-Ordovician diversification on the one hand, and the rifting of the Late Paleozoic supercontinent Pangea with
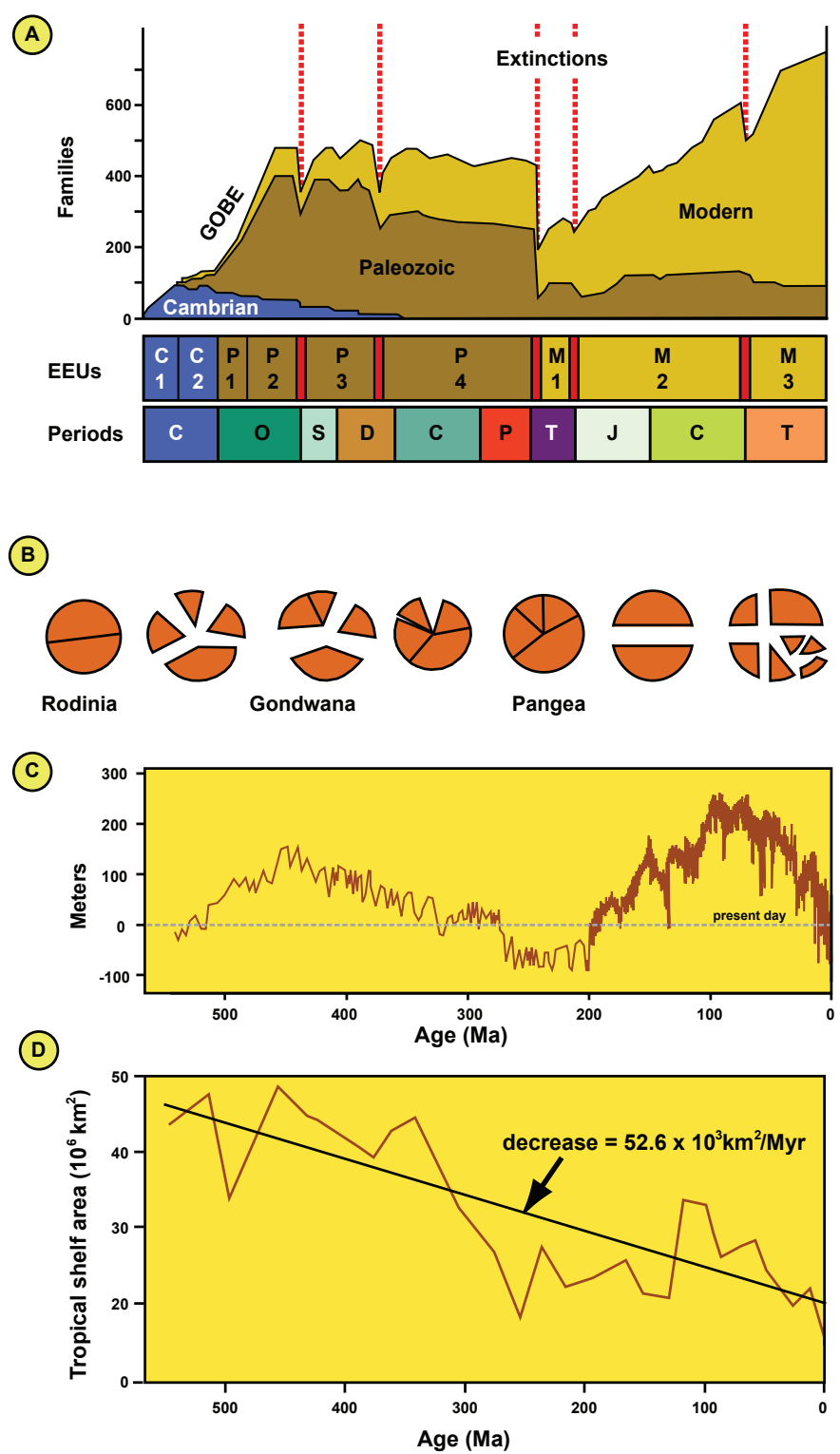

Figure 1. (A) The classical "Sepkoski" diversity curve of marine invertebrate families through Phanerozoic time, documenting the Cambrian, Paleozoic, and Modern Evolutionary Faunas, the Great Ordovician Biodiversification Event (GOBE), and the "Big Five" mass extinctions of marine invertebrates. Ecological-Evolutionary Units (EEUs) after Sheehan (1996): C1-2-Cambrian; P1-4-Paleozoic; M1-3-Modern. Geological periods, from left to right: C-Cambrian; O-Ordovician; S-Silurian; D-Devonian; C-Carboniferous; P-Permian; T-Triassic; J-Jurassic; C-Cretaceous; T-Tertiary. (B) Model of continental spreading with the supercontinents Rodinia and Pangea, based on Valentine and Moores (1972). (C) Phanerozoic global sea-level curve after Miller et al. (2005). (D) Abundance of tropical shelf areas over Phanerozoic time, after Walker et al. (2002).

the Mesozoic-Cenozoic radiations on the other. According to this model, geological intervals with supercontinents correlate with lower marine diversity, while periods with widely separated continents and large numbers of microcontinents can be related to intervals of higher diversity (Fig. 1B).

The Ordovician had the greatest continental dispersal of the Paleozoic and was a time of rapid sea-floor spreading. A number of separate continents had emerged and separated after the 
break-up of the Proterozoic Rodinia supercontinent, including Gondwana, South China, Laurentia, Baltica, and Siberia (Cocks and Torsvik, 2002, 2006). Rifting of the margins of Gondwana gave birth to a number of terranes and microcontinents, such as Avalonia, that drifted rapidly away. Magmatic and tectonic processes generated a number of archipelagos, such as those of the Celtic province (Harper et al., 1996). These paleocontinents and additional minor terranes reached their maximum separation during the Ordovician (Fig. 2); this separation, differences in latitude, and changes in major ocean circulation currents brought about the greatest geographical differentiation of faunas on Earth. While the description of bioprovinces was originally limited to benthic fossil groups (see Fortey and Cocks, 2003), faunal and microfloral provinces have subsequently also been recognized in many planktonic and nektonic organisms (Servais et al., 2003, 2005).

By the late Ordovician, several of these crustal blocks were moving toward each other again, with a consequent loss of biogeographical identity. Baltica and Laurentia, together with Avalonia, formed Laurussia during the Silurian. In the Devonian, Gondwana started to collide with Laurussia, and the Carboniferous amalgamation of all the continents led to the supercontinent Pangea, with a consequent reduction of flooded continental shelf areas (Cocks and Torsvik, 2006).
It is interesting to compare the Ordovician oceanic distribution with the modern-day oceans; today, the centers of marine diversification are in the tropical shelf sea areas of Southeast Asia and, to a lesser extent, the Caribbean Sea. The Ordovician was not only a period with the greatest continental separation but also the geological interval with the largest tropical shelf area in Earth's history (Walker et al., 2002). The extent of global shelves increased from the Early Cambrian to a maximum during the Middle Ordovician; they decreased to their lowest levels at the Permian-Triassic boundary (Walker et al., 2002). A similar extent of global shelves was reached in the Late Cretaceous, but it was not as great in the tropics as it was during the Middle Ordovician (Fig. 1D).

\section{ORDOVICIAN CLIMATE AND SEA LEVEL}

A primary objective of IGCP 503 has been to understand the relationship between biodiversification of the different fossil organisms and changes in seawater temperatures, sea level, and atmospheric $\mathrm{CO}_{2}$. Until recently, the Ordovician was considered to be part of an extended greenhouse period, punctuated by the short-lived Late Ordovician Hirnantian glaciation (e.g., Brenchley et al., 1994). This glaciation was a causal factor in the first of the five major mass extinctions in the Phanerozoic (Harper and Rong, 1995; Sheehan, 2001b)

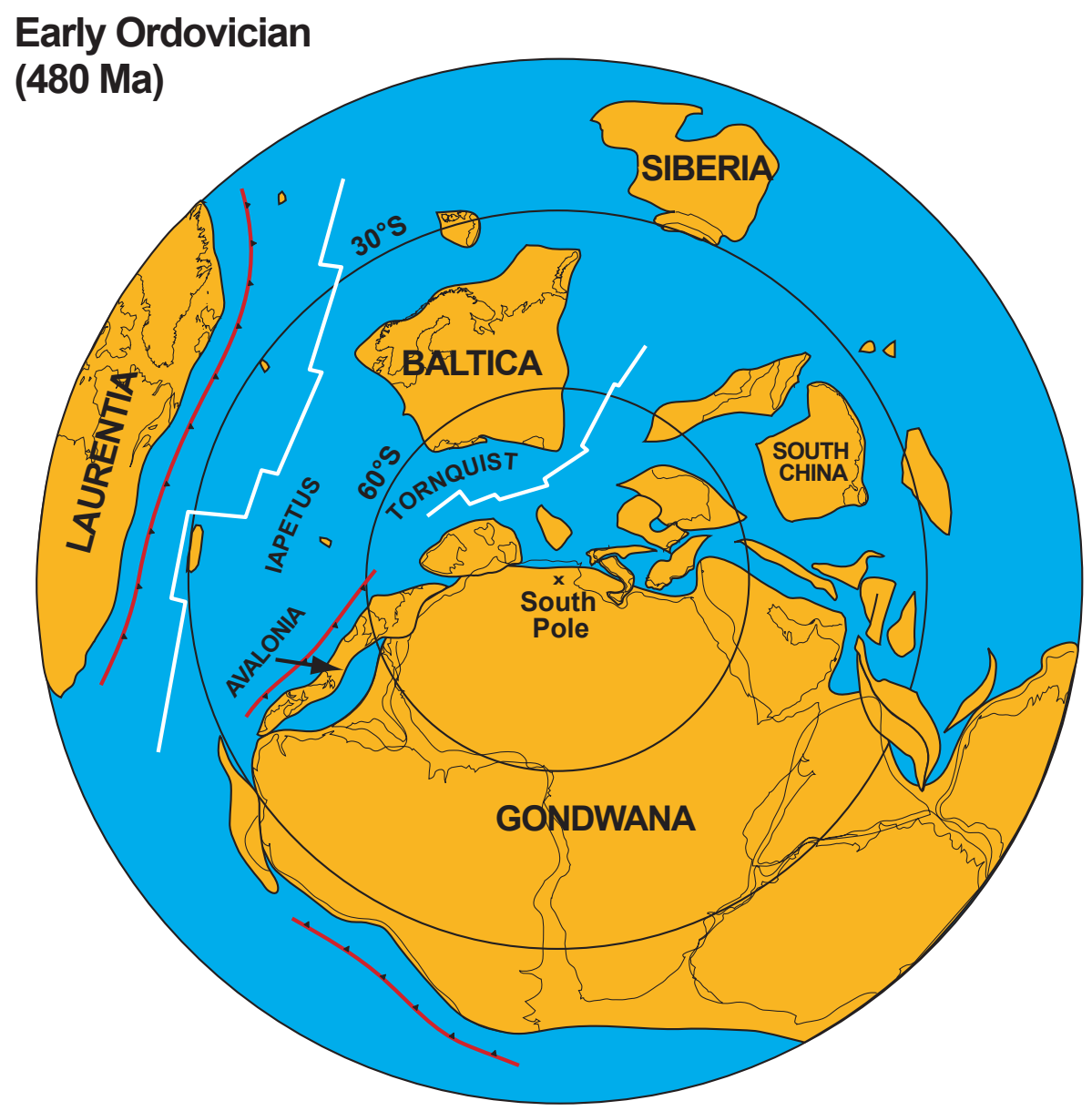

Figure 2. Early Ordovician paleogeographical reconstruction, based on Cocks and Torsvik (2002). 
that severely interrupted the biodiversification process. The late Ordovician cooling is now recognized to have taken place over a more extensive period as a sequence of cooling and warming events that started during the Katian (mid- to late Caradoc) (e.g., Saltzman and Young, 2005) and culminated in the Hirnantian glaciation.

Saltzman (2005) argued that during the greenhouse period, which spanned most of the Cambrian and Ordovician, large positive $\delta^{13} \mathrm{C}_{\text {carb }}$ excursions were absent, indicating a stable interval between the Late Cambrian Steptoan and the Late Ordovician isotope excursions. The stable conditions during most of the Early and Middle Ordovician may have been conducive to the development of the GOBE. However, Trotter et al. (2008) argued that a significant cooling of the Ordovician oceans triggered the biodiversification. They used ion microprobe oxygen isotope analyses of Early Ordovician-Silurian conodonts to indicate a steady cooling of the Ordovician tropical seawater from levels $>40{ }^{\circ} \mathrm{C}$ in the lowermost Ordovician to values of 28-32 ${ }^{\circ} \mathrm{C}$ by the Middle Ordovician, when the GOBE took place. These values correspond to temperature ranges in modern oceans. However, the Trotter et al. model contradicts previous temperature models (e.g., Veizer et al., 2000), and further investigations are needed to clarify whether conodont thermometry is a reliable tool for inferring the seawater temperatures of ancient oceans.

In terms of atmospheric $\mathrm{CO}_{2}$, the Cambrian-Ordovician levels of $\mathrm{PCO}_{2}$ are considered to be the highest in the Phanerozoic, reaching up to 15 times present day (Quaternary average) values (e.g., Berner and Kothavala, 2001). These high levels of $\mathrm{pCO}_{2}$ were critical for maintaining a favorable climate for life, because solar luminosity was much lower than today (e.g., Gibbs et al., 1997). The presence of a mantle superplume, as postulated by Barnes (2004b), could have contributed to high $p \mathrm{CO}_{2}$ levels but may also have increased seawater temperature.

During the dispersal of tectonic plates in the Ordovician, which resulted in abundant young oceanic crust, sea levels were high-possibly the highest in Earth's history (e.g., Hallam, 1992; Barnes, 2004a). There are few precise Ordovician sea-level curves, and intercontinental correlations remain speculative (e.g., Ross and Ross, 1992; Nielsen, 2004); however, there is a consensus that sea levels were on a rising trend, albeit interrupted by regressions, from the earliest Cambrian (when they were similar to those of the present day) to the Late Ordovician, when levels reached $>200 \mathrm{~m}$ above present-day levels (e.g., Haq and Schutter, 2008). Sea levels decreased during the latest Ordovician to reach a minimum during the glaciation near the Ordovician-Silurian boundary before a further significant rise took place during the Llandovery. The Cambrian to mid-Ordovician interval, therefore, is characterized by a long-term sea-level rise that took place over 90-100 Ma. This sea-level rise can be correlated with an extended CambrianOrdovician radiation. The sea-level fall in the latest Ordovician can be related to the first of the "Big Five" mass extinctions, while the subsequent sea-level rise in the Llandovery accompanied the post-extinction recovery (Fig. 3C). Smaller-scale sea-level changes of second or third order are difficult to interpret, and future research is needed to relate regional sealevel curves with the biodiversification of fossil groups from individual paleocontinents.

\section{ORDOVICIAN PALEOECOLOGY: REVOLUTION IN THE TROPHIC CHAIN?}

Paleoecological changes can be considered at four hierarchical levels: (1) the appearance and/or disappearance of an ecosystem; (2) structural changes within an ecosystem; (3) community-type changes; and (4) community-level changes (Bottjer et al., 2001; Harper, 2006). Bottjer et al. (2001) identified changes at the second, third, and fourth levels throughout the GOBE. The most obvious change is the transition from the trilobite-dominated Cambrian EF to the suspension-feeder-dominated Paleozoic EF. Other important changes in the benthos include the evolution of deep-mobile burrowers, above-substrate tiering, and the set-up of new reef communities based on stromatoporoids and corals.

Early work suggests that the increased presence of phytoplankton after the Late Cambrian stimulated the evolution of organisms to feed on this new food source and to extend their ranges into new benthic and pelagic habitats (Bambach, 1983, 1993). A "phytoplankton explosion" may, therefore, have been a trigger for the GOBE (Vecoli et al., 2005; Lehnert et al., 2007). Servais et al. (2008) considered the major arrival of planktonic organisms during the GOBE as a revolution in the marine trophic chain. According to these authors, the Early Cambrian to Late Ordovician increase of sea level and the related expansion of continental shelf areas to their maximum extent in the Middle to early Late Ordovician led to a slow but continuous increase in the diversity of organic-walled microphytoplankton (acritarchs). This is analogous to the development of the dinoflagellates (now the dominant part of Recent organic-walled microphytoplankton), which reached their greatest diversity at the end of the Cretaceous, some $100 \mathrm{Ma}$ after their first appearance in the Triassic.

Servais et al. (2008) showed that the acritarch diversity increased during the Early and Middle Ordovician to reach its highest Paleozoic values during the late Middle Ordovician (Fig. 3B). Similar high levels of acritarch diversity were maintained during the subsequent Silurian and Devonian "Paleozoic phytoplankton plateau." The acritarchs probably represent an important part of the Paleozoic organic-walled microphytoplankton, but it is not possible to relate acritarch diversity directly to increased bioproductivity (abundance). It seems likely, however, that the increased presence of food in the water column promoted the expansion of suspension feeders in the benthos and the development of zooplanktic groups in the pelagic realm (e.g., Vannier et al., 2003).

The presence of dinoflagellate-like microphytoplankton in Ordovician seas thus not only led to the development of the suspension feeders that dominate the Paleozoic EF, but also to the rise of zooplanktonic organisms (graptolites, chitinozoans and radiolarians, etc.), which probably served as food for the many predators swimming freely in the water column. This "plankton revolution" fits with the development of abovesubstrate tiering (Ausich and Bottjer, 1982) and the view that the increased food supply in the water column was responsible for the rise of suspension feeders (Signor and Vermeij, 1994). Rigby (1997) noted that planktic groups mostly developed from the benthos; groups of animals with planktic larvae were able to become planktic adults by paedomorphosis. The migration to the planktic realm occurred throughout the late Proterozoic 
and Phanerozoic and seems to have occurred randomly through time (Rigby, 1997); however, it is now evident that some groups already present in the Cambrian only diversified in the Ordovician, and this was possibly related to the increased presence of microphytoplankton (but possibly of picoplankton and bacterioplankton as well) in the water column.

Interestingly, the plankton revolution is also observed within larval stages of various organisms. Planktonic feeding
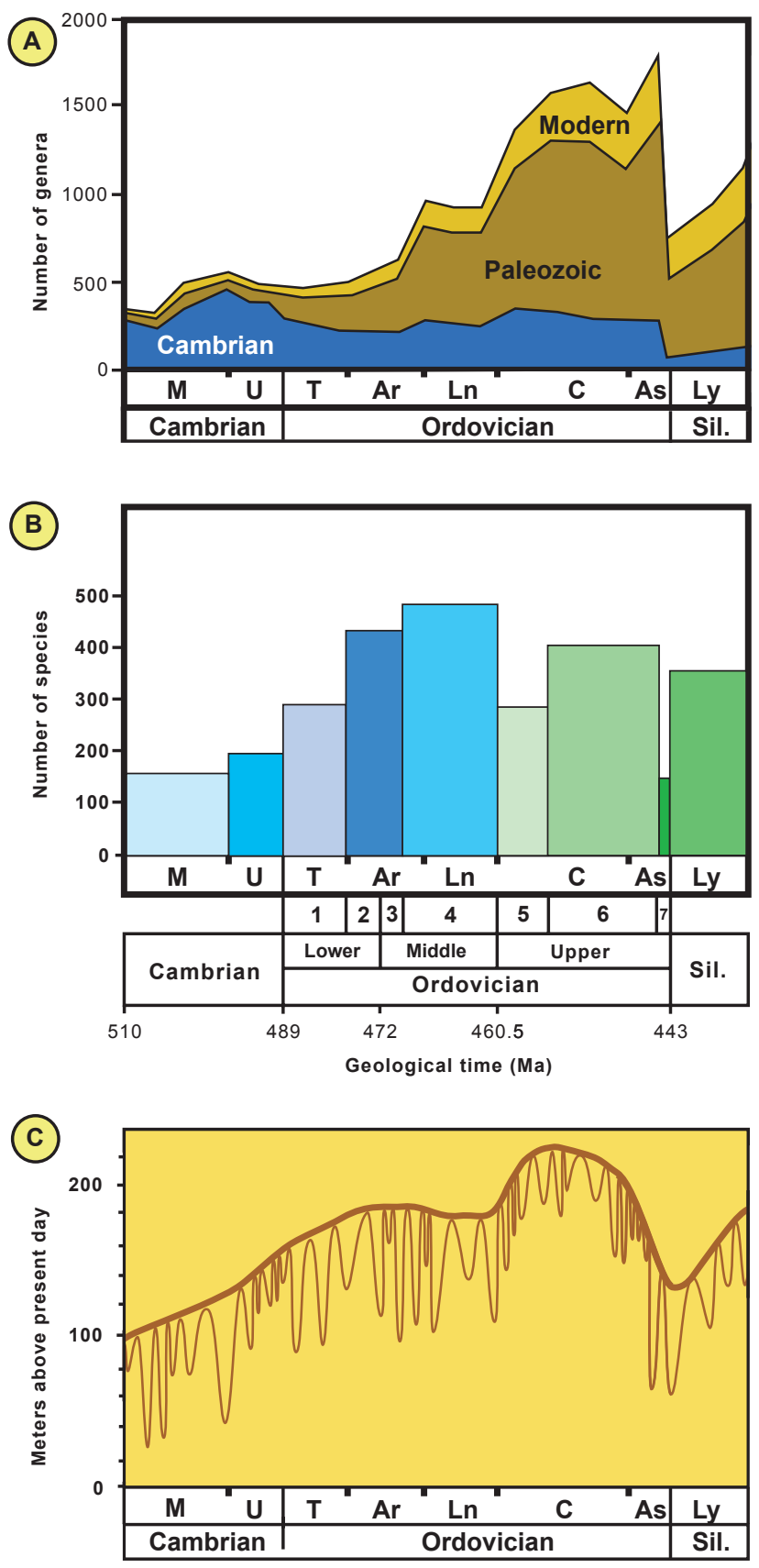

Figure 3. Correlation of diversity curves of (A) marine invertebrates (Webby et al., 2004, their figure 1.1.); (B) organic-walled microphytoplankton (Servais et al., 2008, their figure 1); and (C) the global sea level (Haq and Schutter, 2008). M-Middle Cambrian; U-Upper Cambrian; T-Tremadoc; Ar-Arenig; Ln—Llanvirn; C-Caradoc; As—Ashgill; Ly—Llandovery (British series); 1-Tremadocian; 2-Floian; 3-Dapingian; 4-Darriwilian; 5-Sandbian; 6-Katian; 7-Hirnantian (Global Stages); Sil.—Silurian. larvae developed after the Late Cambrian, possibly as an escape strategy from increasing predation pressure due to the appearance of benthic suspension feeders (Signor and Vermeij, 1994). Nützel et al. (2006) found the first direct evidence for planktotrophy in gastropods at the Cambrian-Ordovician transition. Molecular-clock data and analysis of the fossil record also support this interpretation, with Peterson (2005) noting that planktotrophy evolved independently between the latest Cambrian and Middle Ordovician at least four different times in multiple lineages.

There is thus now enough evidence to suggest that the evolution from the Cambrian EF to the Paleozoic EF, as recognized some 30 years ago, is the result of an important change in the base of the food chain between the Cambrian and Ordovician. While Precambrian and Cambrian communities were mostly limited to the sea bottom, the Ordovician radiation filled the water column as animals adapted to life in previously unoccupied ecospace. Benthic organisms tiered higher above the substrate and increased burrowing depth while plankton increased dramatically. Furthermore, habitats that had been occupied in the Cambrian were invaded by new groups.

\section{OTHER POSSIBLE TRIGGERS OF THE GOBE}

Coupled with the movement of the continents and terranes, the Ordovician (together with the Cretaceous) saw the most extensive volcanism in the Phanerozoic (e.g., Bergström et al., 2004; Barnes, 2004b), possibly including superplume activity during the main interval of the GOBE (Barnes, 2004b). As well as affecting global climate, volcanism would deliver large amounts of inorganic nutrient to the oceans, as would the erosional products of the mountain belts produced by collision of terranes with continental margins, such as the CaledonianAppalachian orogen. It is likely that the abundant trace elements supplied to the oceans provided fuel for the GOBE.

A more spectacular but controversial proposal is that the GOBE is related to the $470 \mathrm{Ma}$ disruption in the asteroid belt of the L-chondrite parent body, the largest documented asteroid breakup event in the past few billion years (Schmitz et al., 2008). Parnell (2009) considered the Middle Ordovician megabreccias found on several palaeoplates and terranes to have formed as a result of seismic activity following a high influx of meteorites. Schmitz et al. (2008) recorded meteorites and craters from Baltoscandia together with extraterrestrial chromite and osmium isotopes in strata from Baltoscandia and China and suggested that the impacts on Earth of kilometer-sized asteroids accelerated the biodiversification. Paris (2008) pointed out that the major problem with the data set of Schmitz et al. (2008) is that the GOBE does not match the timing of the impacts. However, Schmitz et al. (2008) noted that the global stratigraphic data set is too crude to test for correlation of the GOBE with the increased flux of meteorites and extraterrestrial chromite on Baltica, but where accurate faunal data are available, from, for example, western Russia (Rasmussen et al., 2007), there is a precise match.

The asteroid impact hypothesis highlights two important points. First, bed-by-bed collection of data is necessary to test many of the emerging and provocative models for the GOBE. Second, some aspects of the GOBE are diachronous (e.g., Zhan and Harper, 2006); what may work for Baltica may not neces- 
sarily apply in South China. This reinforces the plea by Miller (e.g., 1997, 2004) to dissect the global patterns of biodiversity change at smaller geographical scales and in different taxonomic groups in order to understand them.

\section{CONCLUSIONS}

The GOBE may have had Cambrian roots and can be viewed as a follow-up to the Cambrian explosion. Body plans had to be in place before diversifications at lower taxonomic levels could follow. The "Cambrian explosion" and the GOBE seem indeed to be linked as part of a single, large-scale evolutionary package of marine life that developed over $100 \mathrm{Ma}$, but the significant time lag between the two requires explanation. On the global scale, some of the terrestrial processes that may have promoted the GOBE were part of a continuum from the Cambrian into the Middle Ordovician: continental divergence and the development of new terranes with their own provincial structures, the increase in shelf area (including that in the tropics), and climate and sea-level change. Volcanic activity and tectonism may have been more episodic as, certainly, was asteroid impact. Many of the terrestrial processes were interrelated and impinged on both the benthos and the plankton, and the revolution in the latter probably had a major effect on the former. The GOBE probably had more to do with positive feedbacks and the crossing of thresholds than with abrupt triggers. The recent international research effort has enhanced our understanding of many of the processes involved. The cumulative effect of these processes was a massive increase in diversity within the major clades that developed in the Cambrian explosion and set the scene for the rest of the Paleozoic.

\section{ACKNOWLEDGMENTS}

This paper is a contribution to the International Geoscience Programme (IGCP) 503, "Ordovician Palaeogeography and Palaeoclimate." We thank all participants in this program and also those of the previous IGCP 410, "The Great Ordovician Biodiversification Event," particularly its leaders, Barry Webby (Sydney), Mary Droser (Riverside), and Florentin Paris (Rennes). Chris Barnes (Victoria) and Carlton Brett (Cincinnati) are acknowledged for reviewing the manuscript and providing useful comments.

\section{REFERENCES CITED}

Alroy, J., and 34 others, 2008, Phanerozoic trends in global diversity of marine invertebrates: Science, v. 321, p. 97-100, doi: 10.1126/ science. 1156963.

Ausich, W.I., and Bottjer, D.J., 1982, Tiering in suspension-feeding communities on soft substrata throughout the Phanerozoic: Science, v. 216, p. 173-174, doi: 10.1126/science.216.4542.173.

Bambach, R.K., 1983, Ecospace utilization and guilds in marine communities through the Phanerozoic, in Tevesz, M., and McCall, P., eds., Biotic Interactions in Recent and Fossil Benthic Communities: New York, Plenum, p. 719-746.

Bambach, R.K., 1993, Seafood through time: Changes in biomass, energetics, and productivity in the marine ecosystem: Paleobiology, v. 19, p. $372-397$.

Barnes, C.R., 2004a, Ordovician oceans and climates, in Webby, B.D., Droser, M.L., Paris, F., and Percival, I., eds., The Great Ordovician Biodiversification Event: New York, Columbia University Press, p. $72-76$.

Barnes, C.R., 2004b, Was there an Ordovician Superplume event? in Webby, B.D., Droser, M.L., Paris, F., and Percival, I., eds., The Great Ordovician Biodiversification Event: New York, Columbia University Press, p. 77-80.
Barnes, C.R., Fortey, R.A., and Williams, S.H., 1995, The pattern of global bio-events during the Ordovician Period, in Walliser, O.H., ed., Global Events and Event Stratigraphy: Berlin, Springer-Verlag, p. $139-172$.

Bergström, S.M., Huff, W.D., Saltzman, M.R., Kolata, D.R., and Leslie, S.A., 2004, The greatest volcanic ash falls in the Phanerozoic: Millbrig and Kinekulle K-bentonites: The Sedimentary Record, v. 2, no. 4, p. 4-7.

Berner, R.A., and Kothavala, Z., 2001, GEOCARB III: A revised model of atmospheric $\mathrm{CO}_{2}$ over Phanerozoic time: American Journal of Science, v. 301, p. 182-204, doi: 10.2475/ajs.301.2.182.

Bottjer, D.J., Droser, M.L., Sheehan, P.M., and McGhee, G.R., Jr., 2001, The ecological architecture of major events in the Phanerozoic history of marine life, in Allmon, W.D., and Bottjer, D.J., eds., Evolutionary Paleoecology. The Ecological Context of Macroevolutionary Change: New York, Columbia University Press, p. 35-61.

Boucot, A.J., 1983, Does evolution take place in an ecological vacuum? II: Journal of Paleontology, v. 57, p. 1-30.

Brenchley, P.J., Marshall, J.D., Carden, J.A.F., Robertson, D.B.R., Long, D.G.F., Meidla, T., Hints, L., and Anderson, T.F., 1994, Bathymetric and isotopic evidence for a short-lived late Ordovician glaciation in a greenhouse period: Geology, v. 22, p. 295-298, doi: 10.1130/ 0091-7613(1994)022<0295:BAIEFA >2.3.CO;2.

Cocks, L.R.M., and Torsvik, T.H., 2002, Earth geology from 500 to 400 million years ago: A faunal and palaeomagnetic review: Journal of the Geological Society, v. 159, p. 631-644, doi: 10.1144/0016764901-118.

Cocks, L.R.M., and Torsvik, T.H., 2006, European geography in a global context from the Vendian to the end of the Palaeozoic, in Gee, D.G., and Stephenson, R.A., eds., European Lithosphere Dynamics: London, Geological Society Memoir 32, p. 83-95.

Crame, J.A., and Owen, A.W., eds., 2002, Palaeobiogeography and Biodiversity Change: The Ordovician and Mesozoic-Cenozoic Radiations: London, Geological Society Special Publication 194, 206 p.

Droser, M.L., and Finnegan, S., 2003, The Ordovician radiation: A followup to the Cambrian explosion: Integrative and Comparative Biology, v. 43, p. 178-184, doi: 10.1093/icb/43.1.178.

Droser, M.L., and Sheehan, P.M., 1997, Palaeoecology of the Ordovician Radiation: Resolution of large-scale patterns with individual clade histories, palaeogeography and environments: Geobios, v. 30, p. 221-229, doi: 10.1016/S0016-6995(97)80027-7.

Droser, M.L., Bottjer, D.J., and Sheehan, P.M., 1997, Evaluating the ecological architecture of major events in the Phanerozoic history of marine invertebrate life: Geology, v. 25, p. 167-170, doi: 10.1130/ 0091-7613(1997)025<0167:ETEAOM>2.3.CO;2.

Fortey, R.A., and Cocks, L.R.M., 2003, Palaeontological evidence bearing on global Ordovician-Silurian continental reconstructions: Earth-Science Reviews, v. 61, p. 245-307, doi: 10.1016/S00128252(02)00115-0.

Gibbs, M.T., Barron, E.J., and Kump, L.R., 1997, An atmospheric $p \mathrm{CO}_{2}$ threshold for glaciation in the Late Ordovician: Geology, v. 25, p. 447-450, doi: 10.1130/0091-7613(1997)025<0447:AAPCTF> 2.3.CO;2.

Hallam, A., 1992, Phanerozoic Sea-Level Changes: New York, Columbia University Press, $266 \mathrm{p}$.

Haq, B.U., and Schutter, S.R., 2008, A chronology of Paleozoic sea-level changes: Science, v. 322, p. 64-68, doi: 10.1126/science.1161648.

Harper, D.A.T., 2006, The Ordovician biodiversification: Setting an agenda for marine life: Palaeogeography, Palaeoclimatology, Palaeoecology, v. 232, p. 148-166, doi: 10.1016/j.palaeo.2005.07.010.

Harper, D.A.T., and Rong, J.Y., 1995, Patterns of change in the brachiopod faunas through the Ordovician-Silurian interface: Modern Geology, v. 20 , p. $83-100$.

Harper, D.A.T., Mac Niocaill, C., and Williams, S.H., 1996, Palaeogeography of early Ordovician lapetus terranes: Integration of faunal and palaeomagnetic data: Palaeogeography, Palaeoclimatology, Palaeoecology, v. 121, p. 297-312, doi: 10.1016/0031-0182(95)00079-8. 
Lehnert, O., Vecoli, M., Servais, T., and Nützel, A., 2007, Did plankton evolution trigger the Ordovician diversifications?: Acta Palaeontologica Sinica, v. 46, p. 262-268.

Miller, A.I., 1997, Dissecting global diversity patterns: Annual Review of Ecology and Systematics, v. 28, p. 85-104, doi: 10.1146/annurev. ecolsys.28.1.85.

Miller, A.I., 2004, The Ordovician Radiation: Towards a new global synthesis, in Webby, B.D., Droser, M.L., Paris, F., and Percival, I., eds., The Great Ordovician Biodiversification Event: New York, Columbia University Press, p. 380-388.

Miller, K.G., Kominz, M.A., Browning, J.V., Wright, J.D., Mountain, G.S., Katz, M.E., Sugarman, P.J., Cramer, B.S., Christie-Blick, N., and Pekar, S.F., 2005, The Phanerozoic record of global sea-level change: Science, v. 310, p. 1293-1298, doi: 10.1126/science.1116412.

Nielsen, A.T., 2004, Ordovician sea level changes: A Baltoscandian perspective, in Webby, B.D., Droser, M.L., Paris, F., and Percival, I., eds., The Great Ordovician Biodiversification Event: New York, Columbia University Press, p. 84-93.

Nützel, A., Lehnert, O., and Frýda, J., 2006, Origin of planktotrophyevidence from early molluscs: Evolution \& Development, v. 8, p. 325-330, doi: 10.1111/j.1525-142X.2006.00105.x.

Paris, F., 2008, Meteoritic spur to life?: Nature Geoscience, v. 1, p. 18-19, doi: 10.1038/ngeo.2007.63.

Parnell, J., 2009, Global mass wasting at continental margins during Ordovician high meteorite influx: Nature Geoscience, v. 2, p. 57-61, doi: 10.1038/ngeo386.

Peterson, K.J., 2005, Macroevolutionary interplay between planktic larvae and benthic predators: Geology, v. 33, p. 929-932, doi: 10.1130/ G21697.1.

Peterson, K.J., McPeek, M.A., and Evans, D.A.D., 2005, Tempo and mode of early animal evolution: Inference from rocks, Hox, and molecular clocks: Paleobiology, v. 31, supplement, p. 36-55, doi: 10.1666/ 0094-8373(2005)031[0036:TAMOEA]2.0.CO;2.

Rasmussen, C.M.Ø., Hansen, J., and Harper, D.A.T., 2007, Baltica: A mid Ordovician diversity hotspot: Historical Geology, v. 19, p. 255-261, doi: 10.1080/08912960601151744.

Rigby, S., 1997, A comparison of the colonization of the planktic realm and the land: Lethaia, v. 30, p. 11-17.

Ross, J.R.P., and Ross, C.A., 1992, Ordovician sea-level fluctuation, in Webby, B.D., and Laurie, J.R., eds., Proceedings of the Sixth International Symposium on the Ordovician System, University of Sydney, Australia, 15-19 July 1991: Global Perspectives on Ordovician Geology: Rotterdam, A. Balkema, p. 327-335.

Saltzman, M.R., 2005, Phosphorus, nitrogen, and the redox evolution of the Paleozoic oceans: Geology, v. 33, p. 573-576, doi: 10.1130/ G21535.1.

Saltzman, M.R., and Young, S.A., 2005, Long-lived glaciation in the Late Ordovician? Isotopic and sequence-stratigraphic evidence from western Laurentia: Geology, v. 33, p. 109-112, doi: 10.1130/G21219.1.

Schmitz, B., Harper, D.A.T., Peucker-Ehrenbrink, B., Stouge, S., Alwmark, C., Cronholm, A., Bergström, S.M., Tassinari, M., and Wang, X.F., 2008, Asteroid breakup linked to the Great Ordovician Biodiversification Event: Nature Geoscience, v. 1, p. 49-53, doi: 10.1038/ ngeo.2007.37.

Sepkoski, J.J., Jr., 1981, A factor analytical description of the Phanerozoic marine fossil record: Paleobiology, v. 7, p. 36-53.

Sepkoski, J.J., Jr., 1991, A model for onshore-offshore change in faunal diversity: Paleobiology, v. 17, p. 157-176.
Servais, T., Li, J., Molyneux, S.G., and Raevskaya, E., 2003, Ordovician organic-walled microphytoplankton (acritarch) distribution: The global scenario: Palaeogeography, Palaeoclimatology, Palaeoecology, v. 195, p. 149-172, doi: 10.1016/S0031-0182(03)00306-7.

Servais, T., Blieck, A., Caridroit, M., Chen, X., Paris, F., and Tortello, F., 2005, Use and utility of plankton and nekton for Ordovician palaeogeographical reconstructions: Bulletin de la Société Géologique de France, v. 176, p. 531-543, doi: 10.2113/176.6.531.

Servais, T., Lehnert, O., Li, J., Mullins, G.L., Munnecke, A., Nützel, A., and Vecoli, M., 2008, The Ordovician biodiversification: Revolution in the oceanic trophic chain: Lethaia, v. 41, p. 99-109, doi: 10.1111/j.1502-3931.2008.00115.x.

Sheehan, P.M., 1996, A new look at Ecological Evolutionary Units (EEUs): Palaeogeography, Palaeoclimatology, Palaeoecology, v. 127, p. 21-32, doi: 10.1016/S0031-0182(96)00086-7.

Sheehan, P.M., 2001a, History of marine diversity: Geological Journal, v. 36, p. 231-249, doi: 10.1002/gj.890.

Sheehan, P.M., 2001b, The Late Ordovician mass extinction: Annual Review of Earth and Planetary Sciences, v. 29, p. 331-364, doi: 10.1146/ annurev.earth.29.1.331.

Signor, P.W., and Vermeij, G., 1994, The plankton and the benthos: Origins and early history of an evolving relationship: Paleobiology, v. 20, p. 297-319.

Trotter, J.A., Williams, I.S., Barnes, C.R., Lécuyer, C., and Nicoll, R.S., 2008, Did cooling oceans trigger Ordovician biodiversification? Evidence from conodont thermometry: Science, v. 321, p. 550-554, doi: 10.1126/science.1155814.

Valentine, J.W., and Moores, E.M., 1972, Global tectonics and the fossil record: The Journal of Geology, v. 80, p. 167-184.

Vannier, J., Racheboeuf, P.R., Brussa, E.D., Williams, M., Rushton, A.W.A., Servais, T., and Siveter, D.J., 2003, Cosmopolitan arthropod zooplankton in Ordovician seas: Palaeogeography, Palaeoclimatology, Palaeoecology, v. 195, p. 173-191, doi: 10.1016/S0031-0182(03)00307-9.

Vecoli, M., Lehnert, O., and Servais, T., 2005, The role of marine microphytoplankton in the Ordovician Biodiversification Event: Carnets de Géologie/Notebooks in Geology, Memoir v. 2005/02, p. 69-70.

Veizer, J., Goddéris, Y., and François, L.M., 2000, Evidence for decoupling of atmospheric $\mathrm{CO}_{2}$ and global climate during the Phanerozoic eon: Nature, v. 408, p. 698-701, doi: 10.1038/35047044.

Walker, L.J., Wilkinson, B.H., and Ivany, L.C., 2002, Continental drift and Phanerozoic carbonate accumulation in shallow-shelf and deepmarine settings: The Journal of Geology, v. 110, p. 75-87, doi: $10.1086 / 324318$

Webby, B.D., Droser, M.L., Paris, F., and Percival, I., eds., 2004, The Great Ordovician Biodiversification Event: New York, Columbia University Press, $484 \mathrm{p}$.

Wray, G.A., Levinton, J.S., and Shapiro, L.M., 1996, Molecular evidence for deep pre-Cambrian divergences amongst metazoan phyla: Science, v. 274 , p. 568-573, doi: 10.1126/science.274.5287.568.

Zhan, R.B., and Harper, D.A.T., 2006, Biotic diachroneity during the Ordovician Radiation: evidence from South China: Lethaia, v. 39, p. 211-226, doi: 10.1080/00241160600799770.

Manuscript received 12 December 2008; accepted 29 January 2009. 8 